\title{
LA IDENTIDAD A LA INTEMPERIE: ROBERTO BOLAÑO Y EL PALIMPSESTO DE LA SOLEDAD LATINOAMERICANA
}

\author{
Identity on exposure: Roberto Bolaño and the \\ palimpsest of Latin American solitude
}

Gabriele Bizzarri*

\begin{abstract}
RESUMEN
Este ensayo se propone estudiar el complejo sistema de guiños intertextuales mediante el cual, solapada pero obsesivamente, el macrotexto literario de Roberto Bolaño reenvía a las series narrativas del boom. En efecto, el escritor chileno entabla con los padres narradores del canon local un diálogo intergeneracional entre pares que, superando tanto la necesidad de la imitación fetichista como los límites de la agresión paródica, redefine críticamente el abusado tópico de la identidad latinoamericana acompañándolo hacia una nueva etapa de su evolución.

Palabras clave: identidad latinoamericana, intertextualidad, generación del boom, Roberto Bolaño.
\end{abstract}

\begin{abstract}
This essay aims at studying the powerful but, at first glance, carefully hidden web of intertextual allusions that links Roberto Bolaño's oeuvre to the so-called "boom" narrative series. Indeed, the Chilean author establishes with the founding narrators of the local canon an intergenerational dialogue between equals that, exceeding both the need of fetichist imitation and the limits of parodic deconstruction, critically redefines "Latin American identity", bringing that notorious topic to a new evolutional stage.

Key Words: Latin American Identity, Intertextuality, boom generation, Roberto Bolaño.
\end{abstract}

*Universidad de Padua. Italia. Profesor asociado de Literatura hispanoamericana, Departamento de Estudios Lingüísticos y Literarios. Correo electrónico: gabriele.bizzarri@ unipd.it

Recepción: 30/10/2019. Aceptación: 18/05/2020. 
En este artículo se trata de dar cuenta del lugar estratégico que el fenómeno de la manipulación lingüística de la tradición literaria del boom ocupa en el proceso de revisión del metarelato de la identidad hispanoamericana, según una tendencia que ocupa un lugar privilegiado en la práctica literaria del Nuevo Mundo a partir de los años ochenta del siglo pasado, insinuándose por debajo de la máscara de la adopción de un lenguaje convencionalmente universalista. Polemizando, de hecho, con la cada vez más imponente bibliografía que maneja la literatura hispanoamericana actual a partir de conceptos como el de desterritorialización y global novel, restándole toda especificidad cultural (Montoya Juarez y Estéban, 2008; Volpi, 2009; Aínsa, 2012), se reafirma la resistente centralidad del discurso latinoamericanista que, muy lejos de su extinción, parece estar sondeando nuevas formas (sin duda más laxas y cautelosas) de construir la imagen del sujeto colectivo continental, usando precisamente el potencial ambiguo de la alusividad reescritural para reprocesar las memorias de lo autóctono museográficamente archivadas en las series narrativas del boom.

Como se observa, si en un primer momento, el filtro es el del escepticismo postmoderno y se apuesta por estigmatizar lo estérilmente endogámico del relato periférico de antaño, en una fase más madura del recorrido de elaboración, cuando los escritores aprenden a desprenderse tanto de la lógica de la imitación forzada como de la esclavitud de la deconstrucción condicionada "por un impulso de oposición simétrico al de los modelos cuestionados" (Campra, 2014, p. 24), esos originales secretos empiezan a resonar en los textos como voces de un diálogo intergeneracional franco y desinhibido, del cual la obra de Roberto Bolaño representa un caso paradigmático. 


\section{El círculo vicioso de la(s) reescritura(s)}

Para entender plenamente la metabolización textual de las fuentes señaladas del discurso postcolonial ${ }^{1}$ que caracteriza la obra de Bolaño, es necesario referirse a esa generación de escritores que utilizó el poder del decir "entre comillas" para cuestionar las bases de reconocibilidad colectiva que se fueron conformando en los años sesenta, en lo específico para llevar al descubierto los mecanismos tipificadores y reduccionistas que sustentan la avalancha macondista. El prólogo de la antología Mcondo (1996) evoca la imagen de una ciudad reescritural que, a pesar de la voluntad de los compiladores de llevar a la página el testimonio directo de la megalópolis latina, se sostiene en pie solo en cuanto construcción vicaria de la mera discursividad amasada con materiales provenientes de la autoproclamada destrucción de Macondo, cuyo espíritu originario sigue condicionando puntualmente, por inversión paródica, las estructuras imaginarias instaladas sobre sus ruinas. Queda patente la "debilidad" de este nuevo espacio de definición identitaria que marca el paso del tardío y deliberado acompasamiento de Latinoamérica con el postmoderno internacional, cuyos procedimientos parecen instalarse cómodamente dentro de una precisa tradición de lo local. Siguiendo la idea de la vocación al reciclaje como herencia, el marcador de la reescritura confirma, de hecho, la provocación de Carlos Monsiváis que, reiteradamente en sus obras, describe Latinoamérica como un espacio postmoderno por fuerza propia en una perspectiva transepocal (De Toro y De Toro, 1995): la lógica de la repetición sigue funcionando como figura circular y viciosa del destino latinoamericano, señalado por la imposibilidad de escribir desde la raíz y fundar al ras, transformándose en herencia simbólica de un

\footnotetext{
1 Antes de dar cuenta de las diferentes fases y políticas identitarias que sustentan la narración de lo americano en su fase reescritural, merece la pena observar que el texto postcolonial se conforma, de por sí y en primera instancia, como una revisión discursiva, un enflaquecimiento, de un relato preexistente y canónico: el del centro (Ashcrot, Griffiths y Tiffin, 2002).
} 
descubrimiento que, en realidad, no pudo evitar conformarse como reconstrucción de un espacio ya habitado.

De hecho, lo más valioso de la experiencia mcondista es precisamente la tendencia a desplazar hacia dentro, interiorizar, el mecanismo de la revisión reescritural que el cada vez más institucionalizado canon periférico había utilizado para desenmascarar la naturaleza meramente cultural de las narraciones coloniales sobre el Nuevo Mundo. Ahora, en una temperie cultural que aspira a desmarcarse de la obligatoriedad de la autoctonía, esa misma fórmula queda reciclada para agredir la consistencia de la construcción exotista de la otredad.

Cuando se enfrenta con la práctica creativa madura de los signatarios del manifiesto, la intención iconoclasta que orienta la reescritura se complica y transparenta una franca indecisión frente al problema de si y cómo enterrar (discursivamente) el fantasma de los padres del relato postcolonial. En el ciclo novelesco de Edmundo Paz Soldán, por ejemplo, la pose parricida se diluye ostensiblemente y los tonos de la ironía deconstruccionista se apagan en la nostalgia, enseñando el complejo de infantilización que entrevera hasta los experimentos inter, meta y paratextuales más atrevidos (Bizzarri, 2014). Su novela La materia del deseo (2002) da prueba de una honestad intelectual absoluta por la forma casi didascálica con la que su autor pone en abismo la necesidad del sujeto latinoamericano actual de ir buscándose en un libro canónico, dejándose llevar por la lógica de la repetición como cediendo ante el embrujo de una condena anunciada. Es aquí donde mejor se nota cómo a los nuevos manipuladores textuales parece quedarle muy poco de la carga desestabilizadora que presidía las operaciones reescriturales de los maestros de la generación anterior: lo que un tiempo vehiculaba la digestión caníbal de los relatos del centro, su reterritorialización transgresiva, es ahora un recurso neutro o neutralizado, una respuesta obligada al vértigo de la afasia que se trata de exorcizar buscando refugio (y quedando atrapados) en el laberinto o cuarto cerrado de la 
textualidad, reincidiendo en el vicio genético de deshacer para volver a hacer los mismos pescaditos de oro. El argumento, el regreso de un hijo extraviado a Latinoamérica, el "lugar del padre", para intentar recuperar las "semillas" de su identidad personal y, a la vez, rescatar una imagen supuestamente fiable de ese espacio colectivo que siglos y siglos de textualidades han transformado en frontera inmaterial del deseo y la ilusión, aparece literalmente plagado de guiños a un sistema, el del boom y sus alrededores, que retorna como un fantasma textual homogéneo: no solo García Márquez, sino también Rulfo, Onetti y Cortázar saturan el horizonte en cuanto manifestación polifacética (y, a la vez, monolítica) del relato identitario, cuyas significativas variantes, la dialéctica entre el afincamiento territorial y la dispersión por ejemplo (Cien años de soledad y Rayuela), parecen importar mucho menos que el exasperante entusiasmo que animaba esas búsquedas orgánicas, inhibiendo la construcción de significados nuevos.

El improcedente vagabundeo por las calles de Río Fugitivo, la ciudad imaginaria modelada según los principios mcondistas de la aldea global, es acto obligado que depende de la frustración hermenéutica que le comunica al protagonista la lectura de la novela del padre, reconocible Cronos devorador del canon, en la que se fabula el resistente relato de un río fugitivo todavía enmarañado en la maleza de la selva primordial. Es la incapacidad de dar con la correcta clave de ingreso que le revele el sentido de un clásico literario hasta demasiado reconocible lo que convoca la urgencia de la reescritura desacralizadora: lejos de encontrar la vía de un relevo generacional eficaz, la novela de Paz Soldán deja al escritor novel dramáticamente en suspenso entre la espada de la deconstrucción evasiva y la pared de la relectura estéril. A bien mirar, su posición simbólica es exactamente idéntica a la de los más solitarios entre los Buendía ante el "sanscrito" de los pergaminos de Melquíades. Lo que se reinscribe en un nuevo contenedor textual aquí, en realidad, no es un texto preexistente, sino una entera estructura imaginaria, la de la lectura infructuosa del espejo hablado. Lo que se repite, pues, es la 
lógica de la repetición textual, reconfirmándola como insuperable estigma del imaginario local.

\section{Contra-genética: Roberto Bolaño y las mil mesetas de la nueva narración latinoamericanista}

El círculo de la textualidad cerrada se reabre con Bolaño, conforme a la acción violentamente disgregadora que su entero macrotexto emprende sobre el canon periférico, contaminándolo con modelos culturalmente excéntricos y hasta estéticamente dudosos, haciendo temblar sus jerarquías y destronando a sus paladines, llevando sarcásticamente al descubierto sus automatismos más vergonzosos, en cierto sentido derrumbando estructuralmente la misma noción de canon. Quizá sea por esto que la proliferante bibliografía crítica que de él se ocupa haya omitido, cuando no de una forma meramente anecdótica, investigar la tupida red de alusiones a través de la cual su obra solicita un diálogo con el boom, invitando a sus íconos de referencia fuera de la comfort zone, citándolos en territorios inhóspitos en donde sus voces, beneficiando de una contestación finalmente liberada de todo lastre edípico, acaban por actualizarse derramando significados nuevos. No se trata de rehabilitar la herencia directa de una casta de escritores que Bolaño considera como el peor síntoma de esa tendencia a la institucionalización de la cultura que, en "Los mitos Cthulu", llamando abiertamente en causa al "dueto de machos ancianos formado por García Márquez y Vargas Llosa” (Bolaño, 2010b, p. 542), equipara al fascismo (¿la verdadera literatura nazi en América?), ni obviamente de quitarle peso a la intransigente batalla que emprende para depurar la fruición literaria latinoamericana de todo resabio a "folclore, a color local", sino de resituar su obra en el contexto del debate acerca de la sobrevivencia del relato identitario que lo precede y, en cierto sentido, ilumina. 
En las siguientes páginas se traza la ruta que llega a Santa Teresa, el espacio que, en 2666 (2004), define Hispanoamérica a través de una reescritura abierta de las territorializaciones imaginarias sobre las cuales se ha ido apoyando el peso del canon, intertextualizando la diatriba macondismo/mcondismo para desarmar su misma estructura. En conformidad con la teoría de Ríos Baeza, que en su libro pone al centro del universo Bolaño la noción deconstruccionista de diseminación, se habla cabalmente de una dislocación fronteriza del relato identitario, se aprecia un desplazamiento de la narrativa maestra de la identidad latinoamericana (con sus precedentes adherencias simbólicas) hacia una "zona de indeterminación” donde el canon "se tensa (...) aprovechando algunos de sus elementos temáticos y metodológicos" (Ríos Baeza, 2013, p. 22). Como en el crisol de su textualidad difusa quedarían desdibujados los polos de la oposición binaria norma/heterodoxia, igualmente el espacio cultural latinoamericano se emanciparía del esquema cerrado centro/periferia, beneficiado de la caracterización del sin-norte de la frontera, donde los rasgos identitarios se definen en términos de perpetuo “movimiento y modificación”. Se aplicará entonces la noción de deriva hacia el margen para referirse al re-uso de las narrativas canónicas, que pierden su rumbo como caminantes en el desierto: las piezas del espejo identitario hispanoamericano emprenden, en Bolaño, una fuga irreverente hacia un espacio donde la acumulación caótica de textualidades diversas reemplaza la búsqueda de un reconocimiento colectivo polarizado, convirtiéndose en "imágenes sin asidero", cuya "orfandad" se presta a tramitar un complejo que ahonda sus raíces en la historia literaria del continente y, sin embargo, resituándose en un sistema generalizado y universal de esquivos contactos fronterizos, predispone a la transgresión libertaria de una lógica de la filiación viciosa y enfermiza.

Para él, toda relectura -como cualquier otro intento de acercamiento hermenéuticodesarticula un orden, interrumpe la linealidad genética y extraña la relación entre los elementos implicados. Por eso, su recepción del canon no tiene nada en común con la de 
los habitantes de Mcondo: las cristalizaciones textuales heredadas por la tradición en ningún caso son, en sus manos, fortalezas herméticamente cerradas a protección de un sentido oculto destinadas a convertirse en monolitos de incomprensión o indiferencia, sino territorios abiertos al juego polisémico, zonas de intersección y contaminación horizontal; la reescritura del relato postcolonial (así como la de muchas otras historias) se convierte en pierremenardiana confutación de una jerarquía, cuestionamiento idiosincrático del árbol genealógico de la trasmisión de los significados.

Buen ejemplo de esto es el regreso violentamente anticonvencional en el macrotexto bolañesco del doble vínculo que enlaza el ejercicio literario con la toma de conciencia de la latinoamericanidad. La vocación a la escritura y el estigma de la proveniencia periférica quedan reiteradamente señaladas como interdependientes, con lo cual se produce, sin embargo, un sinfín de distorsiones y efectos perturbadores en los automatismos consabidos que supone un repensamiento radical de lo que significa ser escritor en Hispanoamérica. Si La literatura nazi en América (1993) enmarca el ademán rupturista de un iconoclasta que, para no seguir divulgando los modelos notorios, considera preferible estrenarse ante el público con una historia de las letras continentales hipertróficamente anticanónica y revisionista (hasta lo éticamente inaceptable), el rastreo de estas aberraciones minuciosamente rescatadas por debajo de las tendencias mayoritarias parece esconder una intervención más directa sobre la dependencia del canon oficial latinoamericano de las narrativas identitarias. Una serie de insinuaciones y alusiones delata el asomarse de una cola de cerdo en el retrato de algunos de estos monstruos, a la vez visionarios y grotescos, fijándolos en una precisa genealogía teratológica. Sobre la prodigiosa familia de artistas afincados en la más profunda pampa argentina, los Mendiluce, hitlerianos convencidos, responsables de una traducción al alemán del Martín Fierro alabada por el mismísimo Führer, promotores de una viril poética neogauchesca que, en realidad, se convierte en "punto de referencia obligado" 
para un abstruso circo de nazis, resentidos, alcoholizados, problemáticos de toda cosecha y hasta marginados "sexual o económicamente", se registra el peso de unos "territorios en donde la civilización aún no ha llegado", invitándolos a reflexionar sobre "el destino del continente europeo y el continente americano" (Bolaño, 2010a, p. 17), empujados por la ardiente necesidad de exorcizar el vértigo del apartamiento geográfico y cultural. El peruano Andrés Cepeda Cepeda es autor de una delirante plaquette de inspiración, a la vez, exotérica y patriótica que aspira a "proporcionar un nuevo marco de percepción americana, en donde la voluntad y el sueño se fundirán en una nueva visión de la realidad, en un despertar americano" (Bolaño, 2010a, p. 76): esta reinscripción criptográfica de los términos de lo real maravilloso americano en una perspectiva ideológica criminalmente fundamentalista desemboca en el nacimiento profético "de un niño rubio en las ruinas de una Lima sepulcral" (p. 78) que parece retomar directamente del apocalipsis de Macondo, especulando sobre un retoño en sangre pura de las estirpes condenadas a cien años de soledad. Cerca de Temuco en Chile, al terminar la Segunda Guerra Mundial, se instala la Colonia Renacer, cuyos pobladores son, sin excepción, alemanes: de esta pequeña y secreta incrustación de tránsfugas y proscritos en la desolada vastedad del campo americano y de sus autárquicos rituales de conservación sale el genio literario degenerado de Willy Schurlolz, un pequeño salvaje germánico pervertido por la clausura dedicado a dibujar en el mapa de Latinoamérica curiosos espacios de "concentración” identitaria que son reproducciones precisas de los planos de los campos nazis. Lo más destacable aquí es la movilidad absoluta de los íconos de referencia: las narrativas de la identidad hispanoamericana y sus intenciones originarias sufren un vertiginoso periplo de torsiones y trastornos que las vacía de toda preexistente connotación (izquierdismo, indigenismo, criollización...) hasta volverlas irreconocibles. Poco importa, entonces, que muchos de estos proyectos descabellados de refundación latinoamericanista se basen en el rechazo 
del mestizaje (sinónimo, para muchos de ellos, de "desorden, promiscuidad" y, en cambio, piedra angular de las utopías regeneracionistas del boom).

Lo anterior lo delata la inexplicable anomalía del haitiano Max Mirebalais y su ejército de poetas heterónimos, algo así como un "Pessoa bizarro del Caribe" que no percibe contradicción en "ser un poeta nazi y no renunciar a cierto tipo de negritud" (p. 138) y que después de escenificar una poética identitaria basada alternativamente en el fundamentalismo ariano y en el fundamentalismo masai, acaba por convertirse en un compendio de disfraces que parodian una entera teoría de atractivas variables postcoloniales: "Flor de la orfebrería del plagio de (...) poetas quebecenses, tunecinos, argelinos, marroquíes, libaneses, cameruneses, centroafricanos y nigerianos" (p. 139). La que parece ser la constante de la galería bolañesca es la relación establecida entre el cruce de cables ideológico, el rebrote identitario que desemboca en el chovinismo neonazista y el complejo de exclusión y vicariedad, el total desamparo de sus promotores que se inscriben firmemente dentro de una visión reactualizada y muy bolañesca de la soledad de América Latina. La solución de un intransigente fervor latinoamericanista que, en el intento de defender o reconstruir una completitud amenazada, confunde peligrosamente a Bolívar con Adolf Hitler y crea su propia hilarante mitología, es respuesta grotesca a una marca de la proveniencia que no se deja de tomar en serio y le confiere cierto desesperado heroísmo a los monstruos de la galería. Los dos registros, satírico y épico, se yuxtaponen en la Cosmogonía del Nuevo Orden del colombiano Jesús Fernández Gómez:

El poema (...) narra dos historias que constantemente se intercalan (...): la de un guerrero germano que debe matar a un dragón y la de un estudiante americano que debe demostrar en un medio hostil su valía. El guerrero germano sueña una noche que ha matado el dragón y que sobre su reino se impondrá un nuevo orden. El estudiante americano sueña que debe matar a alguien, (...) que se introduce en la habitación de la víctima y que en ésta sólo encuentra una "cascada de espejos que 
lo ciegan para siempre”. El guerrero germano, tras el sueño, se dirige confiado a la lucha en donde morirá. El estudiante americano, ciego, vagará hasta su muerte por las calles de una ciudad fría (Bolaño, 2010a, pp. 45-46).

Dejando de un lado la wagneriana empresa del guerrero germánico cuya aparición fantasmal encauza el sintomático desarraigo del autor hacia su destino de "falangista americano en Europa" (nada menos), el segundo protagonista, el desamparado estudiante latinoamericano puesto a prueba en un escenario en fuga de soledad y olvido, constituye quizá el prototipo de toda una línea de personajes bolañescos, latinoamericanos y aspirantes poetas todos, que merodean sin rumbo por metrópolis inhóspitas y desiertos baldíos, intersecando sus rutas nómadas a lo largo de todo el continente y yendo a parar, a menudo, al otro lado del Océano (Bolognese, 2010). Esta estirpe condenada, dentro de la cual el propio Bolaño con sus fugas, exilios y bohemias, inscribe su autobiografía, queda convocada a una militancia identitaria que se define por su movilidad sin sosiego $\mathrm{y}$, en este caso, en diálogo intertextual con "la ciudad de los espejos o los espejismos" (García Márquez, 1996, p. 559), a la ceguera implícita en la aceptación de un destino sin norte.

La sección del libro intitulada "Los héroes móviles o la fragilidad de los espejos" contiene el poema de Fernández Gómez en el cual se vislumbra la irremediable trashumancia de los desterrados de Macondo, "las hazañas heroicas de una generación entera de jóvenes latinoamericanos" (Bolaño, 2013, p. 154) por fin identificados con su diáspora. Por esta vía, el fatal desarraigo (existencial y literario) del sujeto colectivo hispanoamericano, ese eco reconocible del canon, se convierte en garantía de natural adiestramiento a una cosmovisión policéntrica, y el insufrible cliché de la latinoamericanidad parece resemantizarse en medio de los escombros de textualidades diversas y dispersas que la conciencia autoral rehúsa hipostasiar fijándolas en una connotación rígida. 
También, esta narrativa identitaria se maneja como un centro de identificación absolutamente móvil, objeto de una nebulosa de auto-reescrituras que, en ciertas ocasiones, corrigen irónicamente el lumpenismo romántico de los perros vagabundos de América Latina, banalizando su repertorio de imágenes o dislocándolo hacia otras periferias.

En el relato "Buba", por ejemplo, la narración de la perenne extranjería que individúa esta trágica vanguardia peregrina no solo se reconstruye en el prosaico desarraigo de un jugador de fútbol chileno fichado por el Barça -apagándose así la seductora aura del exilio de los poetas en la procesión de discotecas y festines de la farándula-, sino que el extremo izquierda chileno objetiva y, parcialmente, exorciza los fantasmas de su origen en el espejo deformado que le proporciona su nuevo compañero de club, un negro africano cuyo inefable y melancólico rostro parece encubrir un misterio impenetrable. El intento retrospectivo de dar un sentido al fugaz pasaje de Buba por su vida da lugar a una fábula de la extrañeza, un verdadero despliegue de señales y marcas de la otredad observadas desde la incorporación imperfecta del narrador a la cosmovisión occidental, pasible, en el marco del multiculturalismo pop que el relato consigue distorsionar inquietantemente, de quedar fracturada por interrupciones simbólicas insospechadas. Mientras el chileno ve por la televisión un "documental sobre los indios del Amazonas sin sonido (...) haciendo tiempo para la hora en que iba a empezar una película del Van Damme” (Bolaño, 2010b, p. 349), desde la habitación de al lado del piso que comparte con Buba le llegan los ruidos repulsivos de una cinta de música africana, cuya alternancia de furiosos tambores tribales, gritos y gemidos alucinados le comunican un horror casi conradiano.

El cuento, empero, desemboca en la creación de un vínculo entre el chileno y este révenant de su propia alteridad reprimida con excesiva desenvoltura: la innombrable participación en un ritual chamánico celebrado en el baño de un departamento que, 
inexplicablemente, empieza a oler "a humedad, a setas, a hongos" (p. 349), y donde se rearman los fragmentos de un discurso primitivo o primitivista que, a pesar de banalizarse en cuanto superstición para meter goles, le entrega al narrador algo parecido al fragmento de un espejo. El sueño que lo visita reconstruye la imagen del origen extraviado:

Soñé que estaba en Santiago otra vez, en mi barrio de La Cisterna, y que estaba recorriendo con mi padre la plaza esa en donde estuvo la estatua del Che (...) hasta que (...) los milicos la volaron definitivamente, (...) y era como si camináramos por el medio de la selva (...). [En] el lugar exacto en donde antes se levantaba la estatua, (...) yo me fijé en (...) una cosa oscura que se movía (...): había un negro en pelotas haciendo dibujos en la tierra y yo supe al tiro que ese negro era Buba (pp. 345-346).

El paisaje de una calle de Santiago vaciado de las señas identitarias de la militancia política por el lavado simbólico de la dictadura, paulatinamente, se metamorfosea en una selva tupida por la cual se conduce una expedición que se sabe de antemano ir a parar a un espacio ciego. Pero ese hueco simbólico está ocupado por la presencia de otra historia igual de errante y silenciada, la cual conjura la reaparición de ciertos apagados destellos telúricos, animistas y hasta mágicos. A través del extrañamiento geográfico y cultural y del apreciable viraje hacia los márgenes de la oficialidad literaria de las engorrosas narrativas maestras de lo postcolonial, se recuperan y ratifican en Bolaño hasta algunas de las piezas más empolvadas e impronunciables del mosaico literario de la identidad latinoamericana.

En otro cuento de la colección, Putas asesinas (2001), "Prefiguración de Lalo Cura", la primera aparición de un personaje emblemático se inscribe firmemente en el marco de la representación bolañesca del destino colectivo del continente a través de una idiosincrática recolocación paródica de la narrativa identitaria del padre ausente en el imaginario del porno. El protagonista, un matón colombiano hijo de un cura renegado y 
una estrella del cine $\mathrm{X}$, reconstruye su infancia pasando lista de los alucinantes fotogramas de las películas protagonizadas por su madre y recordando "la casa de soledad que luego se convirtió en la casa del crimen" (Bolaño, 2010b, p. 295) perdida en medio de la naturaleza salvaje en la cual se afincaba la olvidada y gloriosa Productora Olimpo. La imagen que conduce la serie del rebrote memorial responsable de este chirriante idilio originario es la visión prenatal, surrealistamente amenazadora, de las "pichulas transparentes como gusanos (...) que penetraron a mi madre" (p. 297) durante el embarazo. Los efectos de distorsión y rebajamiento no ocultan la reproposición ambigua de la narración de la ocupación abusiva del lugar de lo materno, la expropiación de un territorio originario: la imagen que Bolaño rescata entre los más sucios desechos del entretenimiento masificado prefigura indudablemente la locura del perpetuo exilio identitario de los latinoamericanos, genéticamente despertados a la vida por la amenaza de un desahucio.

El obsesivo retorno onírico de esta visión vinculante parece orientar la búsqueda del héroe, rulfianamente, hacia un vengativo ajuste de cuentas con esa sombra degradada de lo paterno que se transparenta entre los flujos amnióticos; pero Lalo Cura, moviéndose entre ecos discursivos encontrados (el malinchismo y la antropología de la soledad mexicana de Octavio Paz, entre otros), llega a exorcizar los vergonzosos fantasmas de su mancha identitaria rompiendo el círculo delictuoso de la soledad, abrazando lo irremediable de su condición ilegítima y arrimándose virilmente a la hermandad solidaria de los "bastardos" que, generación tras generación, luchan por afincarse en un centro de satisfacción identitaria y apagar la tensión de un deseo quemante. El cuento se concluye con la celebración ridícula de "la tristeza de esas pollas monumentales en la vastedad y desolación de este continente" (p. 303). Los tonos hasta sublimes que normalmente se aplican al valiente ejército de mártires de la vanguardia, se utilizan aquí para celebrar la estatuaria y viril batalla de los actores pornos de la Productora Olimpo, tantos “jóvenes 
mestizos, negros, blancos, indios, hijos de Latinoamérica (...) cuarteado[s] por la intemperie" (p. 303). Al trágico destino de cada uno de ellos (muertos a balazos, agredidos por el sida, víctimas de dictaduras y revoluciones) se le dedica un hipertrófico catálogo que sabe a hagiografía paródica y corrige, en la ironía, otros momentos parecidos del macrotexto. $^{2}$

La prefiguración desemboca en una precisa genealogía en la reescritura que del personaje de Lalo Cura y sus ignominiosos orígenes se dispone en 2666 (2004), donde su historia se traslada de Medellín a ese lugar totémico del imaginario latinoamericano que es, para Bolaño, México y, más precisamente, la frontera norte y donde el matón a sueldo dispuesto a perdonar se transforma en el único policía de Santa Teresa que, por herencia de la sangre, parece capaz de detectar la marca cultural de los crímenes, el caldo de cultivo antropológico que los justifica y protege. Mientras sus compañeros de patrulla se dedican a contar chistes machistas ratificando estereotipos violentos de la relación entre géneros como una expresión más del folklor mexicano, Lalo Cura, en vez de contestar a las provocaciones que le invitan a una imposible prueba de hidalguía, se queda callado y se deja habitar sin prejuicios por los ecos dispersos de su historia: "Semidormido, varado entre el sueño y la vigilia, escuchaba o recordaba voces que le hablaban de la primera de su familia, (...) una huérfana sin nombre violada por un soldado belga en una casa de adobe de una sola habitación” (p. 693). Se reconstruye así el linaje prodigioso de las Marías Expósito, cinco generaciones de niñas sin padre indefectiblemente violadas por "forasteros borrachos", anónimos absolutos, coroneles de la Revolución y toreros de gira, según las pautas, a la vez mágicas y tragicómicas, de una "rueda giratoria" de puntuales citas con un destino escrito en la sangre que se conforma como un pastiche de Cien años de soledad, en donde el regreso en espiral de figuras cada vez más belicosas de la

\footnotetext{
${ }^{2}$ En primera instancia parece evidente la contigüidad sacrílega de este pasaje con el planctus que la madre de la poesía les dedica a los jóvenes guerreros mártires de América latina en el final de Amuleto (1999).
} 
colonización se reescribe como secuela de conquistas violentas que enajenan el cuerpo femenino.

Este retorno al laberinto de la soledad desemboca en la interrupción de un ciclo: a raíz del azaroso encuentro sexual de la quinta María con dos estudiantes del D. F. perdidos en el desierto de Sonora (a saber, los cabecillas realvisceralistas de Los detectives salvajes, 1998), nacerá un huérfano varón, cuyo bautismo romperá con la tradición familiar para una revisión en nombre y apellido del esquema de la violencia ciegamente perpetrada o padecida. El destino de Olegario Cura parece desmarcarse del monstruo mitológico que, de no haberse llamado Aureliano, hubiera empezado "la estirpe otra vez por el principio" [purificándola] de sus vicios perniciosos y su vocación solitaria” (García Márquez, 1996, p. 552).

El fragmento siguiente al que se consagra la delineación, entre repetición y trasgresión de una reconocible herencia textual, del mapa identitario de la locura da paso a una de las descripciones más significativas de Santa Teresa. Es precisamente la mirada escurridiza de este personaje colectivo la que lleva de plano en medio de una paradoja, invitándo a fijar la imagen de América Latina en un espacio que es pura dispersión:

Vivir en un desierto (...) es como vivir en el mar. La frontera entre Sonora y Arizona es un grupo de islas fantasmales o encantadas. (...) El desierto es un mar interminable. Este es un buen sitio para los peces (...) no para los hombres" (p. 698).

El aprendizaje de lo inestable es una idea que parece central para entender una operación -la fundación de una ciudad llamada Santa Teresa- que, después del escepticismo antilocalista y el humor derramado sobre la consistencia de "este agreste y poderoso territorio imaginario que algunos todavía llaman América Latina” (Volpi, 2009, p. 26), vuelve a proponer la necesidad de reflexionar vanamente sobre el sentido y el rol 
de lo latinoamericano en la corriente osmótica de lo global, lo cual encauza a Bolaño en una línea de "ingeniosa continuación natural de lo que se supone debe ser la Gran Novela Latinoamericana" (Fresán, 2013, p. 15).

Como se sabe, 2666 recibe su bautismo en Amuleto durante el paseo nocturno de la madre de la poesía latinoamericana rastreando la errancia de dos jóvenes realvisceralistas por las avenidas del D. F.: una arteria de tráfico que improvisamente se encandila con los vestigios luminosos de los vehículos transitando sugiere una imagen de fugacidad y dispersión que flirtea con la ciencia ficción y las películas de horror, la de "un cementerio de 2666, un cementerio olvidado debajo de un párpado muerto o nonato, las acuosidades despasionadas de un ojo que por querer olvidar algo ha terminado por olvidarlo todo" (Bolaño, 2013, p. 77). Si se compara la monstruosa imbecilidad de este futurible engendro sin memoria con la mirada clarividente de ese fantasma del deseo identitario insatisfecho, ese arquetipo del latinoamericano errante que, cruzando textualidades dispersas, ha ido a parar en la dimensión fluctuante de la frontera, Santa Teresa, en cuanto lugar del ideal encuentro entre una inadmisible ceguera retrospectiva y una prefiguración de futuro que padece el peso del pasado como una condena anunciada. Este se presenta como un umbral simbólico especialmente denso atravesado por tensiones contradictorias, donde los recuerdos irresueltos del discurso periférico dialogan sin voluntad de síntesis con los simulacros del lavado identitario de la globalización en un espacio donde los puntos de referencia viables se confunden estatutariamente con los espejismos.

De hecho, si es verdad que el desplazamiento del imaginario postcolonial hacia una zona de contacto sugiere la "pérdida de sentido de la noción de una cultura auténtica (...) en un universo autónomo enteramente coherente" (García Canclini, 2001, p. 289), Bolaño no acaba nunca de sintonizar su lectura de la frontera con la dominante entre los border studies de un despreocupado "laboratorio de postmodernidades", donde la emoción de la proximidad vuelve inútil toda vivencia localista. Sus personajes, quienes no son 
latinoamericanos todos pero cuyas historias, convergiendo indefectiblemente hacia Santa Teresa, van articulando todas una reflexión sobre las interdependencias enfermizas que enlazan históricamente y geopolíticamente a Latinoamérica con el mundo, están llamados a moverse por una tierra saturada en reverberaciones textuales en donde elegir entre lo local y lo global, el respeto de la memoria del territorio, con sus automatismos, y el olvido neutralizador se convierte en una opción extremamente delicada. En este sentido, la frontera de Bolaño señala también un limen de la textualidad irresuelta en donde las piezas del debate postcolonial están diseminadas como islas flotantes por la vastedad del relato, ambiguos oasis de un tránsito no lineal, errante, disperso.

Santa Teresa se presenta como un espacio en perenne movimiento y transición constante entre las estaciones (textualizadas) de su pasado y la hipótesis de un futuro de desprovincialización que adquiere tintes igualmente discursivos, como si los diferentes rostros (o máscaras) de construcción identitaria que, desde fuera o desde dentro, han ido conformando la historia del continente se dieran cita y desembocaran en la ingeniería imposible de un dispositivo imaginario proteico, una "máquina" endiablada que "iba a estallar en algún momento, pero la forma del estallido, y cuando ocurriría, era imprevisible" (Bolaño, 2004, p. 405). Una serie de imágenes concordantes se abren en abanico sobre el desierto: "Una escenografía de papel (...) un paisaje humeante” (p. 179), "un enorme campamento de gitanos o de refugiados dispuesto a ponerse en marcha a la más mínima señal" (p. 149). Lo folklórico y lo postindustrial de las maquiladoras conviven en un paisaje urbano lleno de discontinuidades, interrupciones y vacíos simbólicos (lotes baldíos) por donde solo es dado perderse y que se ofrece enigmático al descubrimiento.

Es precisamente una mirada extranjera la que conduce por primera vez al lector de ruta panorámica por la ciudad, lo cual provoca el diálogo con el canon en la repetición del extrañamiento de los primeros cronistas: insensible a la acribia inquisitiva de los 
críticos -que con sus prejuiciosos aparatos hermenéuticos desembarcan dispuestos a colonizar un continente textual-, la región se queda envuelta en una persistente impresión de irrealidad, casi se diría que en un halo mágico. "Les pareció tan caótica que se pusieron a reír (...) un medio hostil (...) un medio cuyo lenguaje se negaban a reconocer, un medio que transcurría paralelo a ellos y en el cual sólo podían imponerse, ser sujetos únicamente levantando la voz" (p. 151). El discurso pronunciado por García Márquez ante la Academia de Suecia, el cual giraba alrededor de la presunción occidental de medir América Latina con su misma vara, se vislumbra el hipotexto ideal, pero lo verdaderamente extraño aquí, lo otro no asimilable, pasa a ser la incapacidad de abandonar la idea misma de "ser sujetos", titulares de un centro fijo. La ridícula movilidad de la "extensa ciudad en el desierto" que, en manos de los archimboldianos, entre estereotipos y monstruosidades se presta a funcionar como enésima figura de la soledad para Amalfitano, el exiliado chileno que hereda la genealogía de la locura y su disponibilidad fluctuante, se convierte en teatro ideal de un naufragio identitario largamente cortejado al que Latinoamérica parece estar invitando "a aquellos convencidos de haber nacido en el lugar mejor del mundo" (Fresán, 2013, p. 15). Tiene razón Rodrigo Fresán al registrar la presencia robusta en Bolaño, al lado de otros referentes totalmente ajenos a la tradición local, "de tranquilizadores destellos mágicorealistas (...) hermosos perdedores, muertos sin tumba, dictadores y Latinoamérica como territorio folk y exótico" (p. 15).

Entre muchas otras cosas, 2666 se presenta al lector como un contenedor textual, un inmenso repertorio o archivo abierto de fragmentos de un discurso latinoamericanista hecho trizas, en el cual las imágenes identitarias, no imantadas alrededor de un polo que las dirija hacia un rumbo o una intención, van tomando direcciones siempre centrífugas, contradictorias, aprendiendo a vagar por el desierto, a quedarse en suspensión y en suspenso, en un perenne estado fronterizo. El desfile insensato e hiriente de las "imágenes 
sin asidero" que, en uno de los pasajes más citados de la novela, contienen "en sí toda la orfandad del mundo" (Bolaño, 2004, p. 265), parece sugerir, en este contexto, la necesidad de tesaurizar y universalizar el incómodo aprendizaje de Lalo Cura por las ramas más alucinantes de su genealogía, convocando a la diáspora identitaria tanto a los sujetos tradicionalmente fuertes (los hijos legítimos) como a los débiles y bastardos, todos invitados a perderse, a quitarse la chaqueta y aprender a ser latinoamericanos.

El detective norteamericano Kessler, mirando sin poder penetrar deductivamente “el paisaje fragmentado o en proceso de fragmentación constante, como un puzzle que se hacía y deshacía a cada segundo" (Bolaño, 2004, p. 752) de Santa Teresa, no puede dejar de exclamar que lo mejor que podrían hacer sus habitantes "es salir una noche al desierto y cruzar la frontera, todos sin excepción, todos, todos” (p. 339). Pero, ¿qué pasaría si América Latina dejara de hurgar en el repertorio, a veces incestuoso, de su pasado y movilizara compacto su tropel de imágenes de reconocimiento hacia el norte? Nos quedaríamos con la sucursal étnica de un fast food, cuya estilización idiotizada y terrorífica es la respuesta más contundente de Bolaño a la opción mcondista. En el Rey del Taco, entre las cebras de Tijuana de un ensamblado mobiliario de sillas de paja y baldosas decoradas, las sombras de los camareros se mueven como sonámbulos llorosos perdidos en el desierto (García Canclini, 2001). Cuando se llegan a ilustrar los dibujos de neón que celebran las aventuras del niño montado en un burro que es el logo de la empresa, entre las reproducciones huecas de la historieta por imágenes de lo mexicano, se dejan colar unos fragmentos que interrumpen la serie sugiriendo un ominoso potencial de resistencia. Sobre ellos, la mirada del consumo imaginario occidental se desliza sin entender, según el consabido automatismo de "lo extraordinario":

En algunas se veía al niño y al burro caer por un desfiladero, en otras se veía al niño y al burro atados a una pira funeraria, e incluso en una se veía al niño que 
amenazaba a su burro poniéndole el cañón de una pistola en la sien (Bolaño, 2004, p. 395).

La sensación de un persistente enigma, o un horrible misterio, en el que van a estallarse las ilusiones de completitud y organicidad de Occidente sigue encantando las imágenes de América Latina que Bolaño rescata por extrañamiento entre los pliegues del canon. ${ }^{3}$ Por su parte, el proceso de despreocupada desprovincialización, con el blanqueado identitario que presupone, está en marcha. Saltar la frontera y optar por la dimisión compacta de las imágenes de lo autóctono significa haber interiorizado a tal punto el vértigo de la bastardía, la soledad de lo ilegítimo, que la única performance identitaria posible parece ser una paradójica búsqueda de hidalguía que, grotescamente, hace eco a las hazañas de los conquistadores, configurándose como uno entre los muchos nombres de lo nazi en América: "Universidad norteamericana, esposa norteamericana (...) A eso le llaman mejorar la raza (...) La clase alta mexicana, de hecho, está haciendo, por su cuenta y riesgo, lo que hicieron los españoles pero al revés” (p. 365). Como señala un periodista sonorense defensor entusiasta de la opción neoliberal, lo único que le falta a Santa Teresa para convertirse en una copia borrosa de Estados Unidos es tiempo: “¿Tiempo para qué?” [Razona escéptico su interlocutor] ¿Tiempo para que esta mierda, a mitad de camino entre un cementerio olvidado y un basurero, se convierta en una especie de Detroit?” (p. 362). Equidistante entre la opción de sucumbir, rulfianamente, en un encierro identitario habitado por los murmullos del pasado, los cuales son obsesiones y se convierten en clichés castradores, y el vertedero en el que,

\footnotetext{
${ }^{3}$ En medio de una velada literaria entre empolvados intelectuales alemanes reunidos en una destartalada taberna de posguerra, una mujer recuerda su encuentro en una estancia perdida en el medio de la pampa argentina con un gauchito insumiso, cuya mirada horrorosamente viva, prácticamente ininteligible, a medio camino entre el deseo sexual y el rencor social, encandila con un "extraño fulgor" las aparentemente apaciguadas piezas del diálogo postcolonial, volviendo a convertirlas en un enigma persistente y tormentoso: "El gauchito miraba la señora desde abajo con una mirada de rapaz, dispuesto a enterrarle un cuchillo a la altura del ombligo y luego subir hasta los pechos, abriéndola en canal, mientras su mirada de carnicerito inexperto brillaba" (Bolaño, 2004, p. 37).
} 
postmodernamente, se entierran definitivamente todas las historias de lo local está la propuesta de la textualidad fronteriza de Bolaño.

De hecho, lo que más salta a la vista son precisamente las drásticas medidas que se van tomando para vacunarse del riesgo de la gangrena identitaria, a través de estrategias con las que Bolaño ya ha estado ensayando en su narrativa anterior: por un lado, la ridiculización paródica de un sistema de referencias que, en cualquier momento, amenaza con (re)producir monstruos incestuosos, apuntando hacia la paradoja de la nazificación del imaginario postcolonial y, por otro, la dislocación geográfica y cultural de lo latinoamericano.

La interpretación frustrada o tipificadora de ciertos reconocibles pilares del debate identitario desemboca en una antropología literaria de pacotilla que justifica la charlatanería premoderna de quién se ocupa de solucionar el enigma de los feminicidios: ¿Quiere decir que Kelly está muerta?, le grité. Más o menos, dijo sin perder un ápice de compostura. ¡O se está muerto o no se está muerto, chingados! En México uno puede estar más o menos muerto, me contestó muy seriamente. Lo miré con ganas de abofetearlo. (...) No, le dije silabeando, ni en México ni en ninguna otra parte del mundo alguien puede estar más o menos muerto. Deje de hablar como si fuera un guía turístico. (...) Estoy harta de los mexicanos que hablan y se comportan como si todo esto fuera Pedro Páramo (Bolaño, 2004, pp. 779-780).

El laxismo y la pasividad con que los autóctonos registran sin pestañear la zombificación - tan cultural, tan exótica- de los sujetos civiles que viven en este lado del mundo provoca una "rabia colectiva o expresión de algo colectivo" (p. 780) por un sentimiento de latinoamericanidad que parece esencializarse alrededor de la condición del homo sacer (Agamben, 2005), expresión trágicamente contemporánea de tantos manierismos fantásticos provenientes del canon. Como cuando dos niñas que asisten al secuestro de su hermana experimentan "lo que era estar en el purgatorio, una larga espera 
inerme, una espera cuya columna vertebral era el desamparo, algo muy latinoamericano, por otra parte, una sensación familiar, algo que si uno lo pensaba bien experimentaba todos los días” (Bolaño, 2004, pp. 659-660). Así, los cercos de contención de la identidad periférica se convierten en barricadas y trincheras amasadas con rencor, difidencia y miedo, justificando el irremediable extrañamiento de los forasteros ante una realidad que se afantasma ad litteram, convirtiendo a sus representantes en sombras irrescatables y hostiles. Se cuenta aquí con otro panorama turístico ideal:

Como si por aquellos lugares hubiera caído una bomba atómica y nadie se hubiera dado cuenta, salvo los afectados (...), pero los afectados no cuentan porque han enloquecido, o porque están muertos, aunque caminen y nos miren, ojos y miradas salidos directamente de una película del oeste, del lado de los indios o de los malos, por descontado, es decir miradas de locos, miradas de gente que vive en otra dimensión y cuyas miradas necesariamente ya no nos tocan, percibimos pero no nos tocan, no se adhieren a nuestra piel, nos traspasan (pp. 752-753).

A primera vista parece descabellado asociar el mapeo fabuloso que de la vieja Prusia antebélica se propone en el comienzo de "La parte de Archimboldi" con las territorializaciones imaginarias que fueron los fetiches de las escrituras del boom. Pero la tentación de relacionar este delirio de liliputianas parcelas identitarias (la Aldea de los Hombres Rojos, la Aldea de las Mujeres Azules, el Pueblo de los Gordos...) a una parodia por infantilización de la geografía imaginaria de la latinoamericanidad se vuelve concreta ante la actitud nómada del futuro escritor, apenas un explorador de visita, que se mueve por estas "aldeas fantasmales, habitadas por muertos" (p. 803), como el latinoamericano vagabundo por las islas encantadas de la frontera, como un buzo o un pez de altura, desdeñando la superficie del mar y "sus olas erizadas por el viento que poco a poco se han ido convirtiendo en metáfora de la derrota y la locura" (p. 797). 
Para evitar las aguas estancadas de un discurso postcolonial desautorizado por su propia complacencia, habrá que acometer sin piedad contra la institucionalización de un imaginario errante que pierde su poder contractual y su potencial perturbador con respecto al del centro en el momento en el que se entroniza cómodamente en medio de un canon que, por excéntrico, no deja de ser menos dogmático y autoritario. La irónica amenaza de un fascismo identitario resituado, de una política y poética de la marginalidad que disfraza detrás de una coartada o un alias la sombra de un proyecto criminal, está a la vuelta de la esquina. Entre los libros que Amalfitano desencaja en los primeros meses de su permanencia en Santa Teresa destaca el de un tal Lonko Kilapán, "Historiador de la Raza, Presidente de la Confederación Indígena de Chile y Secretario de la Academia de la Lengua Araucana" (p. 276), en cuya descabellada narrativa se defiende la tesis de la gloriosa bastardía del Libertador Bernardo O’Higgins, hijo del gobernador de Chile y de una noble araucana, que procedió a su patriótica hazaña ayudado, según el autor, por el don mágico puesto a disposición de los indígenas para derrotar a los españoles: la telepatía.

La reconstrucción de la genealogía del padre de la nación, hijo de un prodigioso mestizaje que, en realidad, esconde el chiste macabro de "un abuso, una violación, una burla (...) usada (...) para cogerse cómodamente a la india” (p. 277), le permite al fantasioso historiador ir trazando una sintomática cartografía de lo chileno, cuyos emigrantes, en tiempos lejanos, "se establecieron primero en el norte de la India, donde fueron llamados arios [y] de ahí se dirigieron a los campos de la primitiva Germania" (p. 283), volviendo luego a esparcir la semilla del mal por tierras patrias. Por esta vía se reconstruye algo parecido a una genealogía nazi de lo mestizo, una absolutización de lo espurio que es puro realismo mágico. El tragicómico adynaton parece cobrar sentido solo si se contextualiza el exotérico panfleto que lo propone en "la atmósfera de triunfo, soledad y miedo" (p. 285) de la dictadura militar y se avanza la hipótesis que el belicoso 
indigenista Kilapán sea, en realidad, "un nom de plume de Pinochet" (p. 286), lo cual Amalfitano hace sumergiéndose en el texto por debajo de la superficie y descubriendo así sus insufribles cruces de cables identitarios.

Emblemáticamente, la parte más viable, menos tramposa, del discurso latinoamericanista de 2666 se aprecia en su migración hacia otros espacios y esferas del diálogo identitario contemporáneo. A través de una saludable e insistida confusión de la referencia directa, América Latina renueva su mitología y se dispone a hablar literalmente fuera de sí. Este "ejercicio de ocultamiento" provoca que el discurso de esta novela políglota y policéntrica, de forma inesperada pero solo aparentemente digresiva, construya un sistema subterráneo (o subacuático) de alusiones a Latinoamérica, diseminando marcas culturales en situaciones, por sorprendentes, no menos estratégicas, como cuando la visión del manicomio suizo les sugiere a los críticos "una sensación extraña. La certeza de que el continente americano no había sido descubierto” (p. 120), o cuando el escritor alemán Benno von Archimboldi, desmarcándose onomásticamente de un fácil malentendido y así exorcizando sus vivencias fascistas, relaciona el nombre de pila de su seudónimo literario con Benito Juárez, o cuando por las calles del gueto negro de Detroit se escucha un estribillo rap cuya letra es la crónica puntual de los feminicidios de Sonora. Trátase de un abanico de variaciones sobre el motivo, tan bolañesco, de la explosión necesaria de los paradigmas de la identidad, del traumático alcance de ese estado límite en el que se aprende a dejar de ser "sujetos", bordeando la locura, el suicidio, el entierro simbólico de la persona en el ácido corrosivo de la literatura o, crucialmente, contemplando la hipótesis de un viaje a América Latina.

En relación con lo anterior, la historia de Fate resulta ejemplar. Se trata de desbaratar las amaneradas manifestaciones identitarias de otro sujeto postcolonial canónico, un afroamericano que, en Estados Unidos, escribe para la revista Amanecer negro, concentrada en divulgar los artefactos seriales de un pintoresquismo sociológico 
políticamente moribundo, y convocarle en México a una inevitable cita con el destino. El fragmento inicial de la parte que se le titula hace saltar de inmediato la chispa de su latinoamericanidad simbólica: la reciente pérdida de la madre lo sintoniza con los andares regresivos de Juan Preciado y, de hecho, la sensación de su orfandad se registra a través de un ramillete de imágenes inequivocables, descontextualizadas ad artem, que le describen "rodeado de fantasmas [sumergirse en] un oscuro lago azteca vagamente familiar" (p. 295).

No obstante, el patrón de la reivindicación vengativa de lo paterno, en cuanto necesaria prueba viril de atestación identitaria, en él se reescribe con una libertad transgresiva que le relaciona con Lalo Cura y su rechazo del estereotipo solitario de la violencia. El esquema de la búsqueda del padre y su rígida orientación lineal están del todo ausentes en la aventura de Fate, quien contesta al estado límite de la pérdida del origen con un cuestionamiento estructural de todo principio identitario, tanto personal como colectivo, lo cual dirigirá sus pasos hacia la frontera, donde su diáspora y la de su raza, perdiendo toda connotación grupal y borrando toda bandera sectorial, acabarán por hermanarse con la de las mujeres mexicanas martirizadas en el desierto, saltando así tanto la categoría del género como la de la etnia. Mientras alrededor suyo, en la superficie de la negociación intercultural fronteriza, se siguen intercambiando clichés de reconocibilidad convertidos en espectáculos (el cine de Spike Lee y el de Robert Rodríguez se utilizan como únicovehículo de comunicación entre la componente negra y la latina del continente), Fate aprende a cruzar fronteras de una forma mucho más substancial, dejando que hablen de él las imágenes aparentemente extrañas del otro, dándose cita múltiples linajes condenados en ese crisol de la marginalidad polimorfa que llega a ser, en manos de Bolaño, Latinoamérica: "Lo que antes era mi derecha ahora es mi izquierda y ya no consigo tener ni un solo punto de referencia. Todo borrado" (p. 438), así como paulatinamente se van borrando en el horizonte del bienintencionado e 
informado lector los mapas e itinerarios notorios de lo periférico hasta que, del círculo cerrado de la repetición que ha terminado por esterilizar las imágenes del repertorio, el viejo tópico del mestizaje americano reaparece intacto y brillante, como recién estrenado, revivificado por el extrañamiento. Mientras, una muchacha medio loca, con quien Hans Reiter hace el amor en una casa donde sólo hay libros nazis, le va hablando de su obsesión fetichista por los aztecas, las burlescas teste composte de un pintor renacentista italiano le sugieren su seudónimo a un escritor alemán que ha militado en el bando hitleriano a través de la mediación de un bolchevique judío exterminado durante la campaña de Rusia, en la intuición de que, independientemente del nombre que se le pretenda dar, "la pureza (...) es puro mariconeo" (p. 981).

Todo eso, permite concluir con una reflexión sobre la identidad de Óscar Amalfitano, el personaje autobiográfico que, justamente a raíz de su traslado a ese lugar totémico de lo latinoamericano universal que es Santa Teresa, emprende un doloroso diálogo con su pasado que sirve de modelo para entender el ambiguo reciclaje de piezas textuales del canon que conforman el entramado de 2666. Amalfitano escucha voces dispersas, como transportadas por el viento, entre las cuales hay una que el personaje identifica borrosamente como el "espíritu de su padre [o el] fantasma de su abuelo" (p. 269). Sus consignas para él, se supone tendrían mágicamente que reorientar su camino, resultan, en cambio, de una intrascendencia enervante, lo cual inscribe el episodio en la estela de las desmitificaciones paródicas del contacto espiritual con los ancestros y sus narrativas maestras emprendidas por los mcondistas. Sin embargo, este exorcismo a la vez privado y colectivo de la tradición no repropone el ademán parricida que esconde un complejo de castración, sino que dirige los pasos del personaje hacia el desierto donde la paternidad y la filiación dibujan formas monumentalmente enigmáticas, esparcidas de manera totalmente azarosa en una zona antijerárquica de libre diseminación: “Allí estaban los padres de las rocas huérfanas (...). Formaciones graníticas, volcánicas, cuyos picos se 
siluetaban en el cielo con formas y maneras de pájaros, pero pájaros de dolor" (p. 262). Cuando para darle un sentido a esta presencia memorial Amalfitano tiene que escoger entre una hipótesis sobrenatural, favorecida por el embrujo folklórico del territorio y su saturación literaria, y admitir el lento deslizarse de su psique por los caminos de la locura, clausura sin remordimientos la casa de los espíritus y escoge dejarse llevar por la resonancia de un nombre que se lleva en los hombros todo el peso de un destino colectivo, reinscribiéndolo en un espacio sin direcciones ni metas donde el tormento del origen (perdido, manchado, violado) empieza a sugerir la ejemplaridad de los viajeros sin descanso, "los aventureros del intelecto, (...) los que no se pueden estar quietos mentalmente" (Bolaño, 2004, p. 257).

Los clásicos del canon periférico, como en la puesta en escena del ready-made de Duchamp que Amalfitano le impone al Testamento geométrico del poeta gallego del exilio Rafael Dieste, se cuelgan a la intemperie, en pleno desierto, en una cuerda tensa, para ver si aprenden cuatro cosas de la vida $\mathrm{y}$, de esta forma, dejan de ser padres incómodos que amenazan constantemente con convertirse en oráculos que frustran y sombras castradoras, sino que se convierten en hermanastros de la textualidad bastarda que desestructura libremente su propia genealogía. Así, de la "historia descompuesta [tantas veces] desarmada y vuelta a armar” (Bolaño, 2004, p. 264) de América Latina (que Bolaño recibe con toda la geológica complejidad de sus multíplices estratificaciones textuales), improvisamente se desprende un objeto inesperado, "una especie de azogue" (p. 264), el espejo líquido, doliente y movedizo de lo americano que vuelve a encantar el conjunto de rocas prehistóricas del paisaje de Sonora como si su imaginario errante tuviera realmente "una segunda oportunidad sobre la tierra" (García Márquez, 1996, p. $559)$. 


\section{Conclusiones}

A lo largo de este recorrido se han llegado a tocar las diferentes estaciones del vía crucis de la latinoamericanidad literaria. Las citas, más o menos explícitas, enterradas en la obra de Bolaño confunden la era gloriosa de las fundaciones (Macondo) con la del derrumbe (Mcondo) en un horizonte discursivo sintomáticamente colgado en el que se celebra, a la vez, la muerte y la resurrección escritural de los viejos clichés. Especialmente notable resulta el rescate de cierto insufrible repertorio: beneficiando de sus parodias cómplices, acostumbrándose, de hecho, a la intemperie textual a la que Bolaño los expone vacunándolos del morbo del fundamentalismo identitario, los clásicos del boom, después de la ecolalia y el cansancio, vuelven a hablar por ventriloquia visionaria, significando toda la urgencia política y la fuerza poética del relato periférico (un relato de diversidad) de cara al ciudadano uniforme del mundo global.

\section{Referencias bibliográficas}

Agamben, G. (2005). Homo sacer. Il potere sovrano e la nuda vita. Torino, Italia: Einaudi.

Aínsa, F. (2012). Palabras nómadas. Nueva cartografía de la pertinencia. Madrid, España/Frankfurt, Alemania: Iberoamericana/Vervuert.

Ashcrof, B., Griffiths, G. y Tiffin, H. (Eds.). (2002). The Empire Writes Back: Theory and Practices of Post-Colonial Literatures. London, Inglaterra: Routledge.

Bizzarri, G. (2014). Reescribir Macondo: América latina como 'modelo para armar' en La materia del deseo de Edmundo Paz Soldán. Orillas, 3, 1-11.

Bolaño, R. (1998). Los detectives salvajes. Barcelona, España: Anagrama.

Bolaño, R. (2004). 2666. Barcelona, España: Anagrama.

Bolaño, R. (2010a). La literatura nazi en América. Barcelona, España: Anagrama.

Bolaño, R. (2010b). Cuentos. Barcelona, España: Anagrama. 
Bolaño, R. (2013). Amuleto. Barcelona, España: Anagrama.

Bolognese, C. (2010). Pistas de un naufragio. Cartografía de Roberto Bolaño. Córdoba, España: Alción.

Campra, R. (2014). Itinerarios en la crítica hispanoamericana. Villa María, Argentina: Eduvim.

De Toro, F. y De Toro, A. (1995). Borders and Margins. Post-Colonialism and Post Modernism. Madrid, España/Frankfurt, Alemania: Iberoamericana/Vervuert.

Fresán, R. (2013). Boomtown o diario para una relectura de Cien años de soledad y apuntes para un proyecto de serie para la $H B O$. Biblioteca virtual Cervantes. http://www.cervantesvirtual.com/nd/ark:/59851/bmcp57b2

Fuguet, A. y Gómez, S. (Ed.). (1996). Mcondo. Barcelona, España: Random House Mondadori.

García Canclini, N. (2001). Culturas híbridas. Estrategias para entrar y salir de la modernidad. Madrid, España: Paidos Ibérica.

García Márquez, G. (1996). Cien años de soledad. Madrid, España: Cátedra.

Montoya Juárez, J. y Estéban, A. (2008). Entre lo local y lo global. La narrativa latinoamericana en el cambio de siglo (1990-2006). Madrid, España/Frankfurt, Alemania: Iberoamericana/Vervuert.

Paz Soldán, E. (2002). La materia del deseo. Madrid, España: Alfaguara.

Ríos Baeza, F. A. (2013). Roberto Bolaño. Una narrativa en el margen. Desestabilizaciones en el canon y la cultura. Valencia, España: Tirant Humanidades.

Volpi, J. (2009). El insomnio de Bolívar. Barcelona, España: Random House Mondadori. 